\title{
EST and Mitochondrial DNA Sequences Support a Distinct Pacific Form of Salmon Louse, Lepeophtheirus salmonis
}

\author{
Ryosuke Yazawa $\cdot$ Motoshige Yasuike • Jong Leong • \\ Kristian R. von Schalburg • Glenn A. Cooper • \\ Marianne Beetz-Sargent • Adrienne Robb • \\ William S. Davidson • Simon R. M. Jones • Ben F. Koop
}

Received: 15 March 2008/Accepted: 20 April 2008 / Published online: 24 June 2008

(C) The Author(s) 2008

\begin{abstract}
Nuclear deoxyribonucleic acid sequences from approximately 15,000 salmon louse expressed sequence tags (ESTs), the complete mitochondrial genome $(16,148 \mathrm{bp})$ of salmon louse, and $16 \mathrm{~S}$ ribosomal ribonucleic acid (rRNA) and cytochrome oxidase subunit I (COI) genes from 68 salmon lice collected from Japan, Alaska, and western Canada support a Pacific lineage of Lepeophtheirus salmonis that is distinct from that occurring in the Atlantic Ocean. On average, nuclear genes are $3.2 \%$ different, the complete mitochondrial genome is $7.1 \%$ different, and $16 \mathrm{~S}$ rRNA and COI genes are $4.2 \%$ and $6.1 \%$ different, respectively. Reduced genetic diversity within the Pacific form of $L$. salmonis is consistent with an introduction into the Pacific from the Atlantic Ocean. The level of divergence is consistent with the hypothesis that the Pacific form of $L$. salmonis coevolved with Pacific salmon (Onchorhynchus spp.) and the Atlantic form coevolved with Atlantic salmo-
\end{abstract}

Electronic supplementary material The online version of this article (doi:10.1007/s10126-008-9112-y) contains supplementary material, which is available to authorized users.

R. Yazawa $\cdot$ M. Yasuike $\cdot J$. Leong $\cdot$ K. R. von Schalburg $\cdot$ G. A. Cooper - M. Beetz-Sargent - A. Robb - B. F. Koop $(\bowtie)$ Centre for Biomedical Research, University of Victoria, P.O. Box 3020 STN CSC, Victoria, BC V8W 3N5, Canada e-mail: bkoop@uvic.ca

W. S. Davidson

Department of Molecular Biology and Biochemistry,

Simon Fraser University,

8888 University Drive,

Burnaby, BC V5A1S6, Canada

S. R. M. Jones $(\square)$

Pacific Biological Station, Fisheries and Oceans Canada,

3190 Hammond Bay Road,

Nanaimo, BC V9T 6N7, Canada

e-mail: simon.jones@dfo-mpo.gc.ca nids (Salmo spp.) independently for the last 2.5-11 million years. The level of genetic divergence coincides with the opportunity for migration of fish between the Atlantic and Pacific Ocean basins via the Arctic Ocean with the opening of the Bering Strait, approximately 5 million years ago. The genetic differences may help explain apparent differences in pathogenicity and environmental sensitivity documented for the Atlantic and Pacific forms of L. salmonis.

Keywords Salmon lice - Lepeophtheirus salmonis .

Expressed sequence tags (ESTs) .

Mitochondrial genome $\cdot 16 \mathrm{~S}$ rRNA .

Cytochrome oxidase subunit I (COI) gene

\section{Introduction}

The salmon louse, Lepeophtheirus salmonis, is an economically important ectoparasite of farmed and wild salmon throughout the northern hemisphere (see reviews by Pike and Wadsworth 1999; Johnson and Fast 2004; Johnson et al. 2004; Boxaspen 2006; Costello 2006). Indirect and direct annual losses due to L. salmonis in the global salmonid aquaculture industry are estimated to exceed US\$ 100 million (Johnson et al. 2004). In addition, elevated abundances of sea lice on wild salmon smolts in coastal waters occupied by salmon aquaculture have led to the hypothesis that wild populations of Atlantic salmonids have been negatively impacted by parasites derived from farmed salmon (Costello 2006). Uncertainty concerning the transmission of $L$. salmonis between farmed and wild salmon populations in British Columbia, Canada, has led to considerable research effort and scientific debate.

The development of the parasite includes two nonparasitic nauplii stages that facilitate dispersal in the plankton, 
an infective copepodid stage, four chalimus stages that are tethered to the host by a frontal filament, two preadult stages, and one adult stage. Preadults and adults are not tethered and are mobile on the surface of the fish. Following mating, adult females produce eggs that hatch to complete the life cycle (see reviews by Johnson and Fast 2004; Boxaspen 2006; Costello 2006). L. salmonis has become an important model for the study of ectoparasitic infestations on salmon. Disease due to $L$. salmonis on Atlantic salmon (Salmo salar) and sea trout (S. trutta) results from the feeding behavior and the secretion of bioactive compounds by the parasite (Pike and Wadsworth 1999; Dawson et al. 1997; Fast et al. 2007). The parasite feeds on mucus, epidermal cells, and underlying tissues causing physical damage, changes in the composition of blood electrolytes, physiological stress, immune dysfunction, impairment of swimming ability, and possibly death (see reviews by Johnson and Fast 2004; Boxaspen 2006; Costello 2006; Tully and Nolan 2002). However, physiological and immunological studies of L. salmonis remain limited (see review by Wagner et al. 2008).

Innate resistance to the salmon louse varies among the various species of salmon and trout (Jones 2001; Johnson and Albright 1992; Fast et al. 2003, 2006). Laboratory studies show that the heaviest infestations and greatest impacts are observed on sea trout (S. trutta) and Atlantic salmon (S. salar) followed by rainbow trout (Oncorhynchus mykiss), chinook (O. tshawytscha), and coho salmon $(O$. kisutch; Dawson et al. 1997; Johnson and Albright 1992; Fast et al. 2002). More recently, pink salmon ( $O$. gorbuscha) were shown to rapidly reject $L$. salmonis and avoid the clinical consequences of infestation (Jones et al. 2007). Morphological and protein data suggest that the development of an inflammatory reaction, both systemically and at the site of parasite attachment, is a distinguishing feature of Oncorhynchus spp. that is not observed in the more susceptible Atlantic salmonids (e.g., S. salar; Fast et al. 2002). The kinetics of these inflammatory processes suggests they play a role in parasite rejection.

Oncorhynchus and Salmo species have been geographically isolated since the Miocene, approximately 18 to 30 million years ago (Devlin 1993; McKay et al. 1996). In light of differential responses of salmon species to lice, the question arises as to whether Atlantic and Pacific parasites such as L. salmonis have coevolved with Atlantic salmon and Pacific salmon, respectively, as distinct populations. Earlier L. salmonis microsatellite data based on six loci identified significant differentiation (fixation index = 0.0595 ) between one Pacific population and Atlantic forms but noted that only $6 \%$ of the overall variation was across oceans (Todd et al. 2004). In addition, a study of four mitochondrial genes noted clear differences between samples from a Japanese population and six Atlantic popula- tions but excluded analysis and reporting of the Japanese data because of reduced length and numbers of sequences (Tjensvoll et al. 2006). In the present study, we examine the mitochondrial genome of the Pacific L. salmonis and compare it to the Atlantic form.

Genomic characterization of Atlantic salmon and rainbow trout (Rexroad et al. 2003; Rise et al. 2004; Govoroun et al. 2006; Adzhubei et al. 2007, Wynne et al. 2008) has enabled an expanded capacity for exploring the salmonid response to infectious disease and other environmental impacts (Rise et al. 2004; von Schalburg et al. 2005). In contrast, the present availability of sequence data from fewer than 200 salmon louse genes (GenBank: Nov 2007) limits our ability to measure and characterize parasite responses prior to and during infection. In the present study, we report on an expression sequence tag (EST) analysis of $L$. salmonis collected from salmon in the Pacific Ocean as part of a larger effort to improve our understanding of the coincident expression of host and parasite genes during infection.

\section{Materials and Methods}

\section{Salmon Lice Samples}

Gravid L. salmonis were collected from postharvest Atlantic salmon reared in seawater net pens in the Broughton Archipelago region of coastal British Columbia, Canada. Dissected egg strings were incubated in four 3-L beakers to permit egg hatching as described earlier (Jones et al. 2007). After 8 days of incubation, copepodids comprised approximately $40 \%$ of the developing lice, and separate suspensions of copepodids and nauplii were obtained in ice-cold filtered seawater by pipetting from a series of $5-\mathrm{mL}$ samples (total volume sampled was $50 \mathrm{~mL}$ ). The copepodid and nauplii suspensions were concentrated onto $0.45-\mu \mathrm{m}$ nitrocellulose membrane filters. The membranes were immediately placed in separate $1.5-\mathrm{mL}$ capped centrifuge tubes, frozen in liquid nitrogen, and stored at $-80^{\circ} \mathrm{C}$. The remaining viable copepodids were used to infect salmon. Sixty naive Atlantic salmon (75g) were maintained in 100 L tanks of filtered seawater and exposed to L. salmonis at a rate of approximately 288 copepodids per fish using the methods of Jones et al. (2007). Parasitic developmental stages of $L$. salmonis were obtained from exposed salmon 9 ( $n=$ ten fish; copepodid, chalimus I), $19 \quad(n=10$ fish, chalimus II, III, IV), and 38days $(n=31$ fish; preadult, adult) after exposure. Immediately following removal from the fish, the specimens belonging to each stage were placed separately in $1.5-\mathrm{mL}$ capped tubes and frozen and stored as described above. For the Pacific salmon louse distribution study, 68 samples of L. salmonis were obtained from 
widely separated locations along the British Columbia coast (Broughton Archipelago: LsBa; Sidney: LsSi; Sooke: LsSo, and Ucluelet: LsUc), Alaska (Port Moller: LsPm; Port of Kodiak: LsPk, and Juneau: LsJu), the mid Bering Sea $\left(180^{\circ}\right.$ $\mathrm{W}$, between $55^{\circ}$ and $57^{\circ} \mathrm{N}$ : LsBs) and Japan (Yoichi, Hokkaido: LsJp; Fig. 1).

mRNA Isolation and Construction of cDNA Libraries

Total ribonucleic acid (RNA) was extracted from frozen samples using TRIzol reagent (Invitrogen) and Poly(A)+ RNA purified by using Poly(A) Purist ${ }^{\mathrm{TM}}$ (Ambion). The non-normalized complementary deoxyribonucleic acid (cDNA) libraries for different developmental stages (copepodid, chalimus I, III, and IV, preadult male, preadult female, adult male, and adult female) were constructed using pBluescript II XR cDNA Library Construction Kits (Stratagene). To obtain enough RNA, particularly from the early stages, several hundreds of individuals were pooled. Poly(A)+RNAs of 2.5 to $5 \mu \mathrm{g}$ were used for each cDNA library following methods previously described (Rise et al. 2004). A normalized library containing equal amounts of RNA from all eight developmental stages was also constructed (Evrogen).

\section{Sequencing, Sequence Analysis, and Contig Assembly}

cDNA libraries were manually arrayed in 384-well microtiter plates, and glycerol stocks of overnight cultures were prepared. Plasmid DNAs were extracted and sequenced on an ABI 3730 DNA analyzer (Applied Biosystems) with M13 Reverse or Forward primers. The resulting ESTs were assembled with CAP3 (Huang and Madan 1999) with default parameters. The assembled total contigs (clusters + singletons) were annotated using RPS-BLAST or BLASTX comparisons with the Conserved Domain Database (www. ncbi.nlm.nih.gov/entrez/query.fcgi? $d b=$ cdd) or SWISSProt (Bairoch and Boeckmann 1992). The best BLAST match ( $E$ value threshold of $1 e^{-10}$ ) was used to identify contigs. Contigs not meeting this threshold were annotated as unknown.

Genomic Characterization and Annotation for the Pacific Sea Lice mtDNA

The total genomic DNAs were extracted from an adult male L. salmonis collected from Broughton Archipelago (British Columbia, Canada) using the following method: A sample placed in 5\% Chelex-100 resin (Sigma) solution (5\% Chelex-100 resin, $0.2 \%$ sodium dodecyl sulfate in Trisethylenediamine tetraacetic acid, with proteinase $\mathrm{K}[100 \mu \mathrm{g} /$ $\mathrm{mL}$ ) was incubated for $30 \mathrm{~min}$ at $55^{\circ} \mathrm{C}$, and the proteinase $\mathrm{K}$ was then inactivated for $10 \mathrm{~min}$ at $90^{\circ} \mathrm{C}$. The polymerase chain reaction (PCR) primer sets were designed for 12 fragments of the Pacific salmon louse (Fig. 2 and Supplemental Table 1) based on the EST sequences encoding mitochondrial DNA (mtDNA) genes and the complete mtDNA genomic sequence previously reported by Tjensvoll et al. (2005). PCR amplification was performed using $1.0 \mu \mathrm{L}$ of extracted total genomic DNA of $L$. salmonis with an initial denaturation step of $2 \mathrm{~min}$ at $95^{\circ} \mathrm{C}$ and then 30 cycles as follows: $30 \mathrm{~s}$ of denaturation at $95^{\circ} \mathrm{C}, 30 \mathrm{~s}$ of annealing at $55^{\circ} \mathrm{C}$, and $3 \mathrm{~min}$ of extension at $72^{\circ} \mathrm{C}$. PCR products were cloned into pCR2.1 vector (TA Cloning Kit, Invitrogen) with the manufacturer's protocol, and each positive PCR product was sequenced as described above.

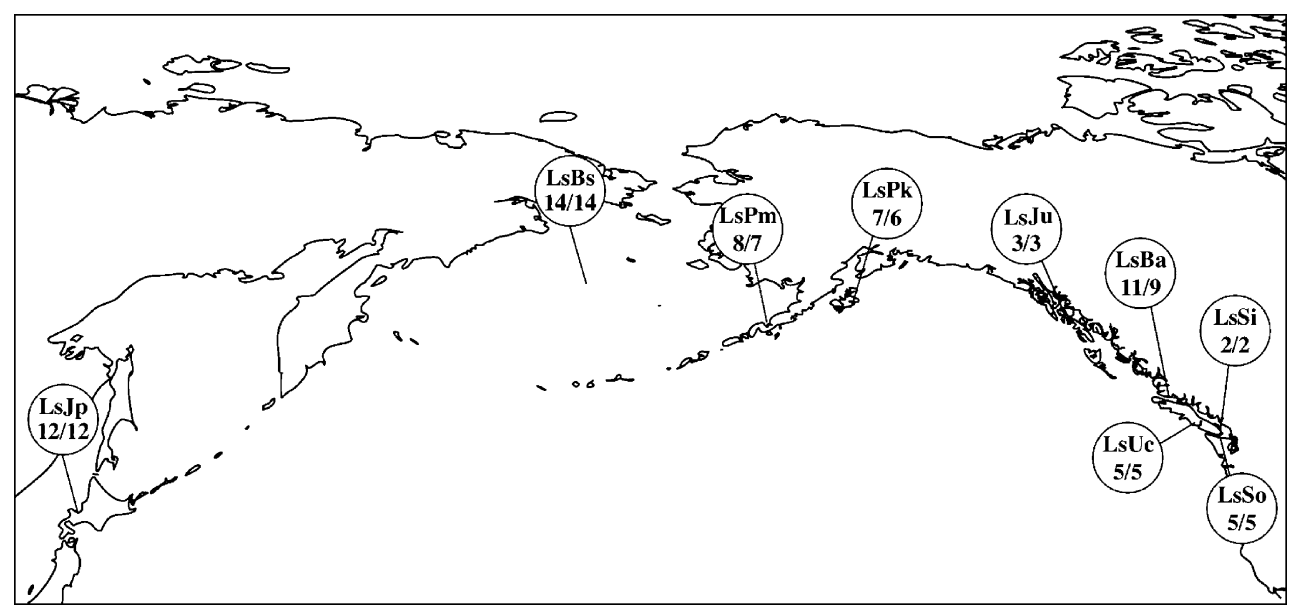

Fig. 1 Map of the northern hemisphere showing the locations Pacific form L salmonis sample site. The sampling locations are shown with sample name (from British Columbia coast, Broughton Archipelago: $L s B a$; Sidney: $L s S i$; Sooke: $L s S o$, and Ucluelet: $L s U c$; from Bering Sea, midway between the Aleutians and Kamchatka: LsBs; Port
Moller: $L s P m$; Port of Kodiak: $L s P k$, and Juneau area: $L s J u$, and from Japan, Yoichi, Hokkaido: $L s J p$ ) and the number of samples sequenced (left: 16S rRNA; right: COI gene) for each location in the circles, respectively 


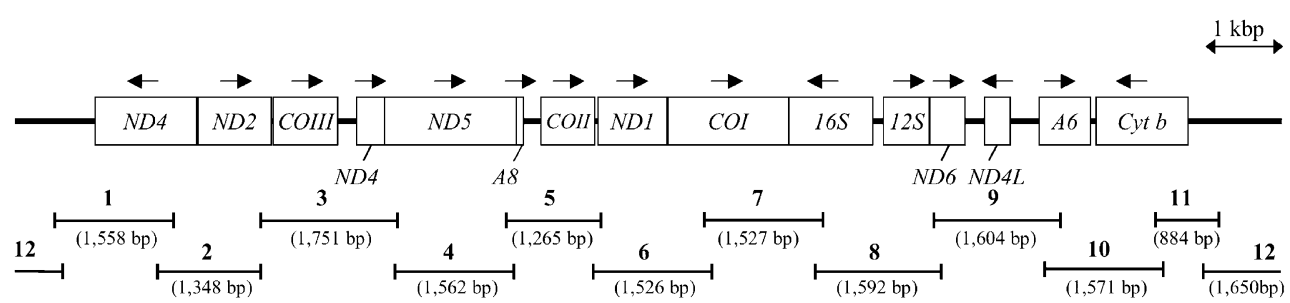

Fig. 2 Genomic organization of the Pacific form L. salmonis mtDNA (16,148bp). Boxes represent each mtDNA gene, and transcription directions are shown by arrowheads. $16 S$ and $12 S$ refer to $16 \mathrm{~S}$ and $12 \mathrm{~S}$ rRNA; COI, COII, and COIII refer to cytochrome oxidase subunit I, II, and III; $C y t b$ refers to cytochrome $b ; N D 1-6$ and $N D 4 L$ refer to

The sequenced clones were assembled using PHRED (Ewing and Green 1998), PHRAP (Ewing et al. 1998), and Consed (Gordon et al. 1998) and annotated using Sequin (Altschul et al. 1990). Dotter (Sonnhammer and Durbin 1995) was used to compare the D-loop region sequences of the Atlantic and Pacific forms.

The Screening for Sequence Variation in COI and $16 \mathrm{~S}$ Genes

Total DNA extracts were obtained from fresh or ethanolfixed samples as described above. The partial gene sequences of the $16 \mathrm{~S}$ ribosomal RNA (rRNA) and cytochrome oxidase subunit I (COI) genes were amplified with the following primer sets: the 16S rRNA, LsPc-16S-F, and LsPc-16S-R; COI gene, LsPc-COI-F and LsPc-COI-R. PCR amplification was performed using $1.0 \mu \mathrm{L}$ of $L$. salmonis genomic DNA with an initial denaturation step of $5 \mathrm{~min}$ at $95^{\circ} \mathrm{C}$ and then 40 cycles as follows: $30 \mathrm{~s}$ of denaturation at $95^{\circ} \mathrm{C}, 30 \mathrm{~s}$ of annealing at $55^{\circ} \mathrm{C}$, and $2 \mathrm{~min}$ of extension at $72^{\circ} \mathrm{C}$. The PCR products were purified with QIAquick PCR purification kit (Qiagen) and directly sequenced with the internal sequencing primers, respectively. All primers used in this study are shown in Supplemental Table 1.

\section{Phylogenetic Analysis}

The partial sequences of the Pacific $L$. salmonis $16 \mathrm{~S}$ rRNA (total of 67 samples) and $\mathrm{COI}$ gene (total of 63 samples) were obtained by the PCRs described above (for 16S rRNA: LsBa; 11 samples, LsSi; two samples, LsSo; five samples, LsUc; five samples, LsBs; 14 samples, LsJu; three samples, LsPm; eight samples, LsPk; seven samples, LsJp; 12 samples. For COI gene: LsBa; nine samples, LsSi; two samples, LsSo; five samples, LsUc; five samples, LsBs; 14 samples, LsJu; three samples, LsPm; seven samples, LsPk; six samples, LsJp; 12 samples; Fig. 1). The $16 \mathrm{~S}$ rRNA and COI gene sequences that were originally identified by Tjensvoll et al. (2006) were used for the Atlantic form of $L$. salmonis sequences (16S rRNA [GenBank: AY602770-AY602949] and COI gene
NADH dehydrogenase subunits $1-6$ and $4 \mathrm{~L}$, and $A 6$ and $A 8$ refer to ATP synthase subunits 6 and 8, respectively. The bars below the diagram show overlaps of PCR amplicons, and their sizes are indicated in parentheses

[GenBank:AY602587-AY602766]). All sequences were trimmed to the same length (16S rRNA; 796bp, COI gene; 1,300bp) and aligned using CLUSTALW (Higgins and Sharp 1988). Distance matrices (Kimura two-parameter) and data for the phylogenic tree were generated by the PHYLIP program package (Felsenstein 1989) using the neighborjoining and unweighted pair group method with arithmetic mean (UPGMA) methods. For simplifying the phylogenic trees, identical sequences were grouped into clusters. The phylogenic trees were generated by NJplot software (Perrire and Gouy 1996).

\section{Results and Discussion}

\section{cDNA Libraries and ESTs}

Independent cDNA libraries were constructed for copepodids, chalimus I, III, and IV stages, male and female preadult, and male and female adult stages of $L$. salmonis. Several hundreds of individual copepodid and chalimus stage individuals were pooled to obtain sufficient RNA quantities. One hundred to 900 sequence reads were obtained from each library and assembled into contiguous sequences (contigs). An analysis of these contigs showed that more than $30 \%$ of the sequences were rRNA gene transcripts indicating very active protein translation. There was also a very high level of transcript redundancy making random sequencing strategies far too inefficient. To obtain the broadest possible representation of genes, equal amounts of messenger RNA from the different life stages listed above were combined, and a normalized cDNA library was constructed. Inserts of 5,760 random clones from this normalized library were sequenced from both the $5^{\prime}$ and $3^{\prime}$ ends resulting in 11,252 total sequences. In the normalized library, the average contig had 1.33 sequences with the largest contig consisting of ten individual sequence reads. A combined total of 14,994 EST sequences from all of the libraries were assembled into 5,256 unique contigs, of which 1,407 were composed of single sequences, 3,849 composed of two or more sequences, and 1,326 of three or 


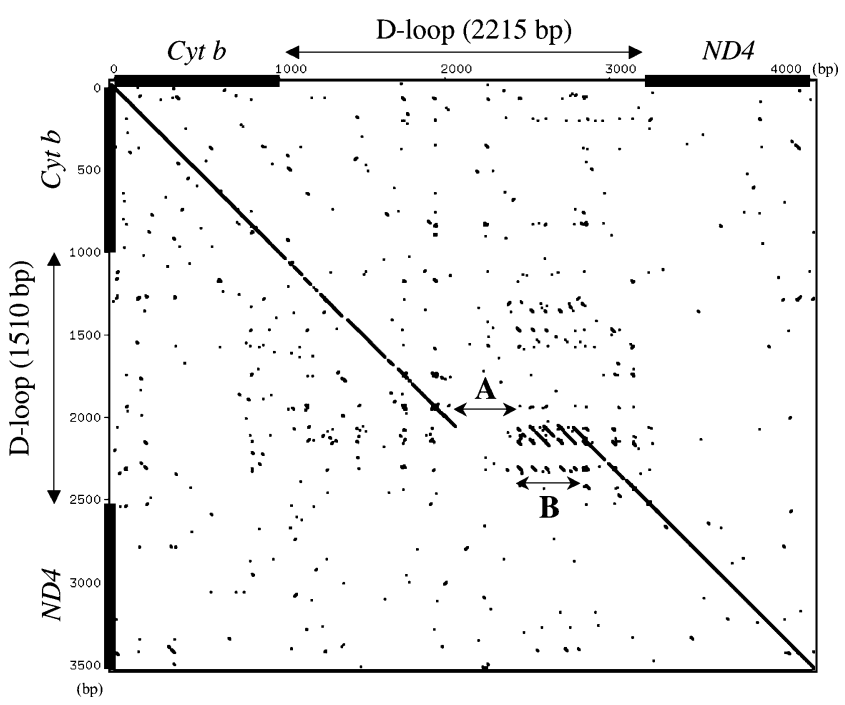

Fig. 3 Dot-matrix analysis of Pacific form D-loop region sequence (horizontal) versus the Atlantic form D-loop region sequence (vertical). Black boxes on the $X$ - and $Y$-axes represent genes on the mtDNA genome. $C y t b$ and ND4 refer to the genes cytochrome $b$ and NADH dehydrogenase subunit 4, respectively. Region $A$ shows missing region in D-loop region of Atlantic form mtDNA. Region $B$ indicated by arrow shows repeat region in Pacific form mtDNA

more sequences. Contigs were annotated by RPS-BLAST or BLASTX comparisons to known protein domain profiles and protein entries in public databases (Conserved Domain Database; www.ncbi.nlm.nih.gov/entrez/query.fcgi? $\mathrm{db}=\mathrm{cdd}$, and SWISS-PROT; Bairoch and Boeckmann 1992). Of the 5,256 contigs, 2,557 matched at least one entry in the databases, and the others remain unidentified. EST sequences are available in GenBank (EX475086-
EX486337) and contigs along with their proposed annotation are available through the cGRASP website (www.uvic. $\mathrm{ca} / \mathrm{cbr} / \mathrm{grasp}$ ). The identification of 5,256 unique contigs provides a novel resource with which to study sea louse biology, as well as serving as the basis for a cDNA microarray. Efforts are currently underway to build a sea louse microarray that will complement existing salmonid microarrays (Rise et al. 2004; von Schalburg et al. 2005) to enable profiling of both host and parasite gene expression during infection.

\section{Comparison of Atlantic and Pacific Form L. salmonis} Genes

A total of 155 of the 5,256 contigs from Pacific $L$. salmonis matched (BLAST $E$ value $<1 e^{-100}$ ) at least one of the approximately 200 nuclear gene sequences from the Atlantic form of $L$. salmonis available in the public databases. These comparisons showed an average of $96.8 \%$ identity over an average of $765 \mathrm{bp}$ (data not shown). The importance of a $3.2 \%$ difference is difficult to determine without knowledge of gene duplications or establishing natural population variation for each gene, and as contig comparisons include $5^{\prime}$ (presumably genic) and $3^{\prime}$ ( 3 ' untranslated region) sequences, they provide only a very rough estimate of overall sequence similarity. However, nuclear gene sequence comparisons do show clear genetic differences between Atlantic and Pacific forms of $L$. salmonis.

Nineteen of the 5,256 EST contigs were identified as mitochondrial sequences and spanned approximately $80 \%$

Table 1 The summary of nucleotide and protein differences between Pacific and Atlantic form

\begin{tabular}{|c|c|c|c|c|}
\hline \multirow[t]{2}{*}{ Genes } & \multicolumn{2}{|c|}{ In nucleic sequence } & \multicolumn{2}{|c|}{ In deduced amino acid sequence } \\
\hline & Identities (bp) & Percent & $\begin{array}{l}\text { Identities (amino } \\
\text { acid residues) }\end{array}$ & Percent \\
\hline $12 \mathrm{~S}$ ribosomal RNA & $583 / 590$ & 98.8 & N.A. & \\
\hline $16 \mathrm{~S}$ ribosomal RNA & $1,037 / 1,070$ & 96.9 & N.A. & \\
\hline Similar to ATPase 8 & $90 / 93$ & 96.8 & N.A. & \\
\hline ATP synthase F0 subunit 6 & $601 / 654$ & 91.9 & $208 / 217$ & 95.9 \\
\hline Cytochrome $b$ & $1,098 / 1,172$ & 93.7 & $383 / 389$ & 98.5 \\
\hline Cytochrome $c$ oxidase subunit I & $1,430 / 1,539$ & 92.9 & $508 / 512$ & 99.2 \\
\hline Cytochrome $c$ oxidase subunit II & $645 / 690$ & 93.5 & $229 / 229$ & 100.0 \\
\hline Cytochrome $c$ oxidase subunit III & $759 / 825$ & 92.0 & $266 / 271$ & 98.2 \\
\hline NADH dehydrogenase subunit 1 & $821 / 885$ & 92.8 & $285 / 294$ & 96.9 \\
\hline NADH dehydrogenase subunit 2 & $845 / 930$ & 90.9 & 293/309 & 94.8 \\
\hline NADH dehydrogenase subunit 3 & $327 / 357$ & 91.6 & $115 / 118$ & 97.5 \\
\hline NADH dehydrogenase subunit 4 & $1,182 / 1,296$ & 91.2 & $399 / 431$ & 92.6 \\
\hline NADH dehydrogenase subunit $4 \mathrm{~L}$ & $313 / 332$ & 94.3 & $107 / 110$ & 97.3 \\
\hline NADH dehydrogenase subunit 5 & $1,524 / 1,680$ & 90.7 & $534 / 559$ & 95.5 \\
\hline NADH dehydrogenase subunit 6 & $423 / 451$ & 93.8 & $146 / 150$ & 97.3 \\
\hline Average & - & 93.4 & & 97.0 \\
\hline
\end{tabular}


of the complete 14.5-kb mtDNA genome of a previously described Atlantic isolate (GenBank: AY625897; Tjensvoll et al. 2005). The EST contigs for Pacific L. salmonis mtDNA genes differed from Atlantic mtDNA by an average of $8 \%$. Similar differences in mitochondrial contigs from the Pacific form were also apparent in comparisons to ATPase subunit 6, COI, cytochrome $b$, and 16S rRNA mtDNA gene sequences from 180 Atlantic Ocean isolates (Tjensvoll et al. 2006).

Characterization of the Pacific Form L. salmonis mtDNA Genome

To determine whether the divergence observed between EST contigs and existing mitochondrial sequences was due to transcriptional or genomic differences, oligonucleotide primers based on conserved sequences within the EST contigs were designed and used to amplify and sequence the complete mtDNA genome of a single Pacific $L$. salmonis individual. Primers based on the EST contigs were effective in amplifying 12 overlapping segments of genomic mtDNA from which we successfully characterized the complete mtDNA genomic sequence (16,148bp; Fig. 2). Structurally, the Atlantic (Tjensvoll et al. 2005) and Pacific mtDNA genomes are identical in gene organization, direction of transcription, and transfer RNA locations (Fig. 2). However, they differ substantially in the D-loop region. The Pacific form D-loop region has a 350-bp insert with respect to the Atlantic form and differs in the number of repeated 70-bp sequences (Fig. 3). Sequence divergence in the D-loop region, not including repeats, is very high (22.7\%). Among mitochondrial genic regions, Pacific and Atlantic forms showed an average of $7.1 \%$ difference (combined 13 mtDNA genes and two rRNA DNA; $11,680 / 12,570 \mathrm{bp})$. Individual gene and protein similarities are shown in Table 1.

\section{Distribution of Pacific Form of L. salmonis}

To examine the distribution of the Pacific mitochondrial form, we amplified and sequenced the 16S rRNA and COI gene from 68 specimens obtained from widely separated locations along the British Columbia coast (Broughton Archipelago, Ucluelet, Sidney, and Sooke), Alaska (Port Moller, Port of Kodiak, and Juneau), the mid Bering Sea $\left(180^{\circ} \mathrm{W}\right.$, between $55^{\circ}$ and $57^{\circ} \mathrm{N}$ ), and Japan (Yoichi, Hokkaido; Fig. 1). These sequences were compared to the 16S rRNA and COI gene sequences previously described from six locations in the Atlantic Ocean (Scotland, Russia, Eastern Canada, and three locations in Norway; Tjensvoll et al. 2006). All Pacific and Atlantic 16S rRNA and COI gene sequences were aligned and phylogenetic analyses performed (Fig. 4). All individual sequences of L. salmonis

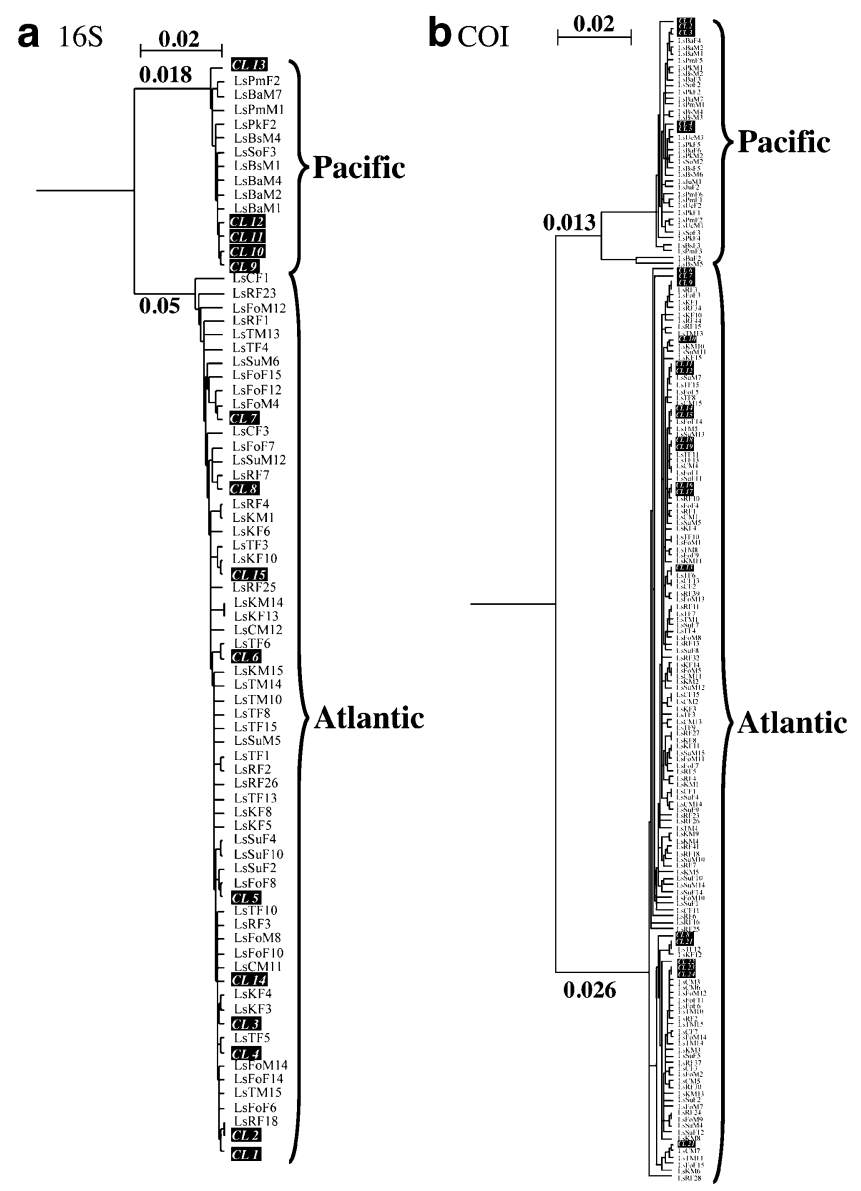

Fig. 4 Molecular phylogeny of Pacific and Atlantic form L. salmonis inferred from a UPGMA analysis of nucleotide sequence of a $16 \mathrm{~S}$ rRNA and b COI mtDNA genes. $C L$ refers to the clusters that contain 2-90 identical sequences and are shown by white letters in black boxes. All clusters consist of only Pacific $(n=67,63)$ or Atlantic $(n=$ $180,180)$ isolates. The numbers of sequences in each cluster are described below. For 16S rRNA, CL1: 90 sequences (sq); CL2, 4, 5, 7, 9, 10, 12, and 13: 2 sq; CL3: 13 sq; CL6 and 8: 3 sq; CL11: 11sq. For COI gene, CL1-7, 10, 13-20, 23-25, 27, 28, 30, and 31: 2 sq; CL8, 9, 11, and 26: 3 sq; CL12: 4 sq; CL21: 9 sq; CL22: 6 sq; CL29: 12 sq. The partial sequences of Caligus elongatus (16S rRNA [GenBank: AY660020] and COI gene [GenBank: AY861371]) were used to root the neighbor-joining trees (not shown in this figure). The numbers are branch lengths from UPGMA analysis. The same major branches were obtained from a neighbor-joining analysis. $M$ or $F$ in the sample names are for the male or female

from the Pacific closely resemble and confirm the Pacific mitochondrial genome sequence and form a single branch, distinct from a branch with representatives from the Atlantic Ocean. Samples from the mid Bering Sea, the closest Pacific location to the Atlantic Ocean, clearly grouped with the Pacific forms. Atlantic and Pacific forms could be uniquely identified by fixed differences at 13 $(100 \%)$ and $22(>95 \%)$ aligned nucleotide positions in the 16S rRNA sequence (in 796bp) and at $26(100 \%)$ and 67 $(>95 \%)$ positions in the COI gene (in $1,300 \mathrm{bp}$ ). The large number of fixed differences between Atlantic and Pacific populations strongly supports a long period of isolation. 
Table 2 The divergence of 16S rRNA and COI genes in and between Pacific and Atlantic forms of L. salmonis

\begin{tabular}{|c|c|c|c|c|c|c|}
\hline & \multicolumn{3}{|c|}{ 16S rRNA (\%) } & \multicolumn{3}{|l|}{ COI $(\%)$} \\
\hline & In Pacific & In Atlantic & Atl vs. Pac & In Pacific & In Atlantic & Atl vs. Pac \\
\hline Average & 0.14 & 0.26 & 4.16 & 0.62 & 0.76 & 6.06 \\
\hline Max & 1.01 & 1.91 & 5.48 & 4.83 & 2.73 & 7.89 \\
\hline Min & 0.00 & 0.00 & 2.95 & 0.00 & 0.00 & 5.06 \\
\hline Stdev & 0.00169 & 0.00267 & 0.00226 & 0.00400 & 0.00770 & 0.00286 \\
\hline
\end{tabular}

"Average" indicates average for Kimura two-parameter distance (K2P) of all samples in each group. "Max" and "Min" refer to the maximum and minimum values of K2P in each group. "Stdev" refers to standard deviation of K2P values in each group. "Atl vs. Pac" indicates the values for $\mathrm{K} 2 \mathrm{P}$ and Stdev between the Atlantic and Pacific isolates

The average difference between the Pacific and Atlantic $L$. salmonis forms is $4.2 \%$ at the $16 \mathrm{~S}$ rRNA locus and $6.1 \%$ at the COI gene locus (Table 2). These differences are greater than those found between different species of Drosophila (Kopp and True 2002; Kastanis et al. 2003). Moreover, the $6.1 \%$ divergence between the COI gene of the Pacific and Atlantic forms is much greater than the $3 \%$ differences between lepidopteran and vertebrate species in the Barcoding programs (Hebert et al. 2003). These results strongly support distinct Pacific and Atlantic forms of L. salmonis. Whether these forms constitute separate species will require additional study as Margolis (1958) found Atlantic and Pacific forms morphologically identical.

The 68 Pacific L. salmonis samples precluded a robust analysis of population structure in the biogeographical distribution of alleles. The evidence for structure among samples collected from the Atlantic was not found in an earlier study (Tjensvoll et al. 2006). The overall average divergence between individuals within the Pacific population is $0.14 \%$ in the $16 \mathrm{~S}$ rRNA locus and $0.62 \%$ in the $C O I$ gene locus. The intraspecific divergence values from the Pacific samples are consistently lower than those seen in the Atlantic form (Table 2) and indicate lower genetic variability within the Pacific salmon louse population. In general, these values are consistent with intraspecific variation found in many other species (Hebert et al. 2003). It is interesting to note that the two most distinct individuals were found at distant locations in the Pacific (LsBs: the mid-Bering Sea and LsBa; Broughton Archipelago, British Columbia; Fig. 4). These two Pacific sea lice individuals differ by $1.8 \%$ from each other and by $3.4 \%$ from the other 61 Pacific isolates at the COI locus, which indicates the possibility of population structure. A more extensive sampling from various Pacific locations is required to determine the existence of population structure.

\section{Conclusions}

These results suggest that the Pacific salmon (Oncorhynchus spp.) and the Pacific salmon louse have coevolved over an extended period of time, in parallel to the coevolution of Atlantic salmonids (Salmo spp.) and the Atlantic salmon louse. On the basis of fossil specimens found in Idaho, pink, chum, and sockeye salmon (Oncorhynchus spp) have been separated into distinct species for at least 6 million years (Smith 1992). Moreover, estimations of the length of separation between Salmo and Oncorhynchus range from 18 to 30 million years (Devlin 1993; McKay et al. 1996) and correspond to $4.3 \%$ and $14.5 \%$ divergences for $16 \mathrm{~S}$

Table 3 Ranges of divergence based on Kimura two-parameter distance and crustacean molecular-clock calibrations

\begin{tabular}{|c|c|c|c|c|c|c|c|c|}
\hline & \multicolumn{5}{|l|}{ 16S rRNA } & \multicolumn{3}{|l|}{ COI } \\
\hline & \multirow[t]{2}{*}{ Distance (K2P, \%) } & \multicolumn{4}{|c|}{ Divergence range (Myr) } & \multirow[t]{2}{*}{ Distance (K2P, \%) } & \multicolumn{2}{|c|}{ Divergence range (Myr) } \\
\hline & & Ano & Fid & Gra (low) & Gra (high) & & Alp & Gra \\
\hline Mean & 4.16 & 10.92 & 3.74 & 6.40 & 4.73 & 6.06 & 2.53 & 3.65 \\
\hline Max & 5.48 & 14.37 & 4.37 & 8.42 & 6.22 & 7.89 & 3.29 & 4.75 \\
\hline Min & 2.95 & 7.75 & 2.66 & 4.54 & 3.36 & 5.06 & 2.11 & 3.05 \\
\hline
\end{tabular}

The values for "Distance" are the median of the Kimura two-parameter (K2P) distance between the Atlantic and the Pacific form L. salmonis in 16S rRNA and COI genes. Rates of molecular evolution used for the $16 \mathrm{~S}$ rRNA gene include $0.38 \% \mathrm{~K} 2 \mathrm{P} / \mathrm{million}$ year (Myr) for anomurans: Ano (Cunningham et al. 1992); 0.90\% K2P/Myr for fiddler crabs: Fid (Sturmbauer et al. 1996), and 0.65 (low) $-0.88 \%$ (high) K2P/Myr obtained from grapsid crabs: Gra (Schubart et al. 1998). COI calibrations were calculated with 2.4\% K2P/Myr obtained from alpheid shrimps: Alp (Knowlton et al. 1993), and 1.66\% K2P/Myr obtained from grapsid crabs: Gra (Schubart et al. 1998) 
rRNA and COI genes. Atlantic and Pacific salmon lice differ by $4.2 \%$ and $6.1 \%$ for $16 \mathrm{~S}$ rRNA and COI genes (Table 2), respectively. These values are not easily comparable since rates of evolution vary tremendously among taxa. However, the divergence between Pacific and Atlantic salmon lice is substantially lower than between Pacific and Atlantic salmon hosts even though the evolutionary rates of mitochondrial genes in copepods are thought to be faster than for vertebrates. Sequence divergences, in conjunction with a molecular clock calibrated by previous copepod studies (Rocha-Olivares et al. 2001), suggest that the Pacific and Atlantic forms of $L$. salmonis diverged 2.5 to 11 million years ago (Table 3 ), roughly corresponding with the first continuous connection between the Pacific and Atlantic oceans through the Bering Strait (5 million years ago; Marincovich and Gladenkov 1999). These estimates are very broad, but it appears that the Atlantic and Pacific forms of the salmon louse arose well after the separation of Atlantic and Pacific salmonids and about the time of the opening of the Bering Strait.

The level of separation between Pacific and Atlantic salmon lice mitochondrial genomes, the estimated time of Pacific and Atlantic salmon louse separation coinciding with the opening of the Bering Strait, and the reduced overall variation found within the $16 \mathrm{~S}$ rRNA and COI genes from Pacific salmon lice all support an Atlantic Ocean origin of L. salmonis followed by a limited introduction into the Pacific Ocean coincident with the opening of the Bering Strait, approximately 5 million years ago. Parallel coevolution of salmon lice on their respective hosts in the Pacific and Atlantic Oceans has resulted in nuclear and mitochondrial genetic changes that may help to explain apparent phenotypic differences observed between these forms. In recent work using Scottish L. salmonis specimens, Bricknell et al. (2006) provided evidence of reduced tolerance of copepodids for low salinity in comparison to similar studies using lice specimens from British Columbia (Johnson and Albright 1992). Similarly, Saksida et al. (2007) documented a lower incidence of disease and a reduced need to treat farmed $S$. salar for $L$. salmonis in British Columbia compared with farmed $S$. salar in Scotland and Norway. More research is required to test these hypotheses. The high level of sequence divergence between the Pacific and Atlantic L. salmonis indicates that a taxonomic revision of these forms may be warranted.

Acknowledgments We would like to particularly acknowledge the efforts of Dr. Jim Seeb, Douglas Eggers, Dick Wilmont, and Mark Witteveen in collecting sea lice samples from all over Alaska, Professor Kazuo Ogawa, Kouki Miura, and Kazuya Nagasawa for samples from Japan, and Fisheries and Oceans for samples from the Bering Sea, western Vancouver Island, and Broughton Archipelago.
We would also like to thank the Sequencing Team at the Michael Smith Genome Sciences Centre, Vancouver, British Columbia, for sequence support. Funding for this study was provided by Genome British Columbia, the province of British Columbia, Microtek International, Mainstream, Marine Harvest, and Grieg Seafoods.

Open Access This article is distributed under the terms of the Creative Commons Attribution Noncommercial License which permits any noncommercial use, distribution, and reproduction in any medium, provided the original author(s) and source are credited.

\section{References}

Adzhubei AA, Vlasova AV, Hagen-Larsen H, Ruden TA, Laerdahl JK, Hoyheim B (2007) Annotated expression sequence tags (ESTs) from pre-smolt Atlantic salmon (Salmo salar) in a searchable data resource. BMC Genomics 8:209-223

Altschul SF, Gish W, Miller W, Myers EW, Lipman DJ (1990) Basic local alignment search tool. J Mol Biol 215:403-410

Bairoch A, Boeckmann B (1992) The SWISS-PROT protein sequence data bank. Nucleic Acids Res 20:2019-2022

Boxaspen K (2006) A review of the biology and genetics of sea lice. ICES J Mar Sci 63:1304-1316

Bricknell IR, Dalesman SJ, O'Shea B, Pert CC, Luntz AJ (2006) Effect of environmental salinity on sea lice Lepeophtheirus salmonis settlement success. Dis Aquat Org 71:201-212

Costello MJ (2006) Ecology of sea lice parasitic on farmed and wild fish. Trends Parasitol 2210:475-483

Cunningham CW, Blackstone NW, Buss LW (1992) Evolution of king crabs from hermit crab ancestors. Nature 355:539-542

Dawson LHJ, Pike AW, Houlihan DF, McVicar AH (1997) Comparison of the susceptibility of sea trout (Salmo trutta L.) and Atlantic salmon (Salmo salar L.) to sea lice (Lepeophtheirus salmonis (Krøyer, 1837)) infections. ICES J Mar Sci 54:1129-1139

Devlin RH (1993) Sequence of sockeye salmon type 1 and 2 growth hormone genes and the relationship of rainbow trout with Atlantic and Pacific salmon. Can J Fish Aquat Sci 50:1738-1748

Ewing B, Green P (1998) Base-calling of automated sequencer traces using PHRED. II. Error probabilities. Genome Res 8:186-194

Ewing B, Hillier L, Wendl MC, Green P (1998) Base-calling of automated sequencer traces using PHRED. I. Accuracy assessment. Genome Res 8:175-185

Fast MD, Ross NW, Mustafa A, Sims DE, Johnson SC, Conboy GA, Speare DJ, Johnson G, Burka JF (2002) Susceptibility of rainbow trout Oncorhynchus mykiss, Atlantic salmon Salmo salar and coho salmon Oncorhynchus kisutch to experimental infection with sea lice Lepeophtheirus salmonis. Dis Aquat Org 521:57-68

Fast MD, Burka JF, Johnson SC, Ross NW (2003) Enzymes released from Lepeophtheirus salmonis in response to mucus from different salmonids. J Parasitol 891:7-13

Fast MD, Muise DM, Easy RE, Ross NW, Johnson SC (2006) The effects of Lepeophtheirus salmonis infections on the stress response and immunological status of Atlantic salmon (Salmo salar). Fish Shellfish Immunol 213:228-241

Fast MD, Johnson SC, Eddy TD, Pinto D, Ross NW (2007) Lepeophtheirus salmonis secretory/excretory products and their effect on Atlantic salmon immune gene regulation. Parasite Immunol 29:179-189

Felsenstein J (1989) PHYLIP_Phylogeny Inference Package Version 3.2. Cladistics 5:164-166

Gordon D, Abajian C, Green P (1998) Consed: a graphical tool for sequence finishing. Genome Res 8:195-202 
Govoroun M, Le Gac F, Guiguen Y (2006) Generation of a large scale repertoire of expressed sequence tags (ESTs) from normalised rainbow trout cDNA libraries. BMC Genomics 7:196-203

Hebert PD, Cywinska A, Ball SL, deWaard JR (2003) Biological identifications through DNA barcodes. Proc Biol Sci 270:313-321

Higgins DG, Sharp PM (1988) CLUSTAL: a package for performing multiple sequence alignments on a microcomputer. Gene 73:237244

Huang X, Madan A (1999) CAP3: a DNA sequence assembly program. Genome Res 9:868-877

Johnson SC, Albright LJ (1992) Comparative susceptibility and histopathology of the response of naive Atlantic. Chinook and coho salmon to experimental infection with Lepeophtheirus salmonis Copepoda: Caligidae. Dis Aquat Org 14:179-193

Johnson SC, Fast MD (2004) Interactions between sea lice and their hosts. Symp Soc Exp Biol 55:131-159

Johnson SC, Treasurer JW, Bravo S, Nagasawa K, Kabata Z (2004) A review of the impact of parasitic copepods on marine aquaculture. Zool Stud 432:229-243

Jones SR (2001) The occurrence and mechanisms of innate immunity against parasites in fish. Dev Comp Immunol 258:841-852

Jones SR, Fast MD, Johnson SC, Groman DB (2007) Differential rejection of salmon lice by pink and chum salmon: disease consequences and expression of proinflammatory genes. Dis Aquat Org 753:229-238

Kastanis P, Eliopoulos E, Goulielmos GN, Tsakas S, Loukas M (2003) Macroevolutionary relationships of species of Drosophila melanogaster group based on mtDNA sequences. Mol Phylogenet Evol 283:518-528

Knowlton N, Weigt LA, Solorzano LA, Mills DK, Bermingham E (1993) Divergence in proteins, mitochondrial DNA, and reproductive compatibility across the isthmus of Panama. Science 260:1629-1632

Kopp A, True JR (2002) Phylogeny of the Oriental Drosophila melanogaster species group: a multilocus reconstruction. Syst Biol 515:786-805

Margolis L (1958) The identity of the species of Lepeophtheirus (Copepoda) parasitic on Pacific salmon genus (Oncorhynchus) and Atlantic salmon (Salmo salar). Can J Zool 36:889-892

Marincovich L, Gladenkov AY (1999) Evidence for an early opening of the Bering Strait. Nature 397:149-151

McKay SJ, Devlin RH, Smith MJ (1996) Phylogeny of Pacific salmon and trout based on growth hormone type-2 and mitochondrial NADH dehydrogenase subunit 3 DNA sequences. Can J Fish Aquat Sci 53:1165-1176

Perrire G, Gouy M (1996) WWW-Query: an on-line retrieval system for biological sequence banks. Biochimie 78:364-369

Pike AW, Wadsworth SL (1999) Sealice on salmonids: their biology and control. Adv Parasitol 44:233-337

Rexroad CE 3rd, Lee Y, Keele JW, Karamycheva S, Brown G, Koop B, Gahr SA, Palti Y, Quackenbush J (2003) Sequence analysis of a rainbow trout cDNA library and creation of a gene index. Cytogenet Genome Res 102:347-354
Rise ML, von Schalburg KR, Brown GD, Mawer MA, Devlin RH, Kuipers N, Busby M, Beetz-Sargent M, Alberto R, Gibbs AR, Hunt P, Shukin R, Zeznik JA, Nelson C, Jones SR, Smailus DE, Jones SJ, Schein JE, Marra MA, Butterfield YS, Stott JM, Ng SH, Davidson WS, Koop BF (2004) Development and application of a salmonid EST database and cDNA microarray: data mining and interspecific hybridization characteristics. Genome Res 143:478-490

Rocha-Olivares A, Fleeger JW, Foltz DW (2001) Decoupling of molecular and morphological evolution in deep lineages of a meiobenthic harpacticoid copepod. Mol Biol Evol 186:10881102

Saksida S, Karreman GA, Constantine J, Donald A (2007) Differences in Lepeophtheirus salmonis abundance levels on Atlantic salmon farms in the Broughton Archipelago, British Columbia, Canada. J Fish Dis 306:357-366

Schubart CD, Diesel R, Hedges SB (1998) Rapid evolution to terrestrial life in Jamaican crabs. Nature 393:363-365

Smith GR (1992) Introgression in fishes: significance for paleontology. Syst Biol 411:41-57

Sonnhammer EL, Durbin R (1995) A dot-matrix program with dynamic threshold control suited for genomic DNA and protein sequence analysis. Gene 167:1-10

Sturmbauer C, Levinton JS, Christy J (1996) Molecular phylogeny analysis of fiddler crabs: test of the hypothesis of increasing behavioral complexity in evolution. Proc Natl Acad Sci USA 93:10855-10857

Tjensvoll K, Hodneland K, Nilsen F, Nylund A (2005) Genetic characterization of the mitochondrial DNA from Lepeophtheirus salmonis Crustacea; Copepoda. A new gene organization revealed. Gene 3532:218-230

Tjensvoll K, Glover KA, Nylund A (2006) Sequence variation in four mitochondrial genes of the salmon louse Lepeophtheirus salmonis. Dis Aquat Org 683:251-259

Todd CD, Walker AM, Ritchie MG, Graves JA, Walker AF (2004) Population genetic differentiation of sea lice (Lepeophtheirus salmonis) parasitic on Atlantic and Pacific salmonids: analyses of microsatellite DNA variation among wild and farmed hosts. Can J Fish Aquat Sci 61:1176-1190

Tully O, Nolan DT (2002) A review of population biology and hostparasite interactions of the sea lice Lepeophtheirus salmonis (Copepoda: Caligidae). Parasitology 124:165-182

von Schalburg KR, Rise ML, Cooper GA, Brown GD, Gibbs AR, Nelson CC, Davidson WS, Koop BF (2005) Fish and chips: various methodologies demonstrate utility of a 16,006-gene salmonid microarray. BMC Genomics 6:126-133

Wagner GN, Fast MD, Johnson SC (2008) Physiology and immunology of Lepeophtheirus salmonis infections of salmonids. Trends Parasitol 24:176-183

Wynne JW, O'Sullivan MG, Cook MT, Stone G, Nowak BF, Lovell DR, Elliott NG (2008) Transcriptome analyses of amoebic gill disease-affected Atlantic salmon (Salmo salar) tissues reveal localized host gene suppression. Mar Biotechnol 10:388-403 